\title{
Attitude of Farmers towards Thai Koi Farming in Selected Upazila of Bangladesh
}

\author{
Farruk Ahmed, Mohammad Zulfikar Rahman, Shonia Sheheli, Debashish Sarker Dev ${ }^{*}$
}

Department of Agricultural Extension Education, Bangladesh Agricultural University, Mymensingh, Bangladesh

\begin{tabular}{l}
\hline A R T I C L E I N F O \\
Research Article \\
Received 03 August 2016 \\
Accepted 21 December 2016 \\
\hline
\end{tabular}

Keywords:

Attitude

Thai Koi farming

Favorable

Nutrition

High growth

$\overline{\text { *Corresponding Author: }}$

\begin{abstract}
A B S T R A C T
The main purposes of the study were to determine the attitude of farmers towards Thai Koi farming in a selected area of Mymensingh district. Attempt was also made to identify the problems faced by the farmers in Thai Koi farming. Data were obtained from randomly selected 70 Thai Koi farmers of Shaiod and Ahmedpur villages in Kheruajani Union under Muktagachha Upazila of Mamensingh district during April, 2015. Attitude of the farmers was measured in respect of different aspects of Thai koi production. A three-point rating scale was used to indicate the Thai koi farmers' response against each statement. The possible score for each respondent could range from 15 to 45 and observed score ranged from 31 to 41 . It is evident that 'I believe that Thai koi farming in pond can supply protein and nutrition to the family members ranked first as a statement in attitude scale of Thai Koi farmers. Second is 'I like Thai Koi farming because it has higher growth rate than that of other local Koi'. Most of the Thai Koi farmers had highly favourable attitude. Among the problems, 'high sensitivity to disease of Thai Koi' got the highest problem confrontation score and stood the first ranked problem and other problem were 'High price of Thai koi feed', High price of drugs' and 'High price of farm labour' etc. Farmers suggested from their experiences that there should have need-based spot training on effective management of Thai Koi farming. In achieving this target, Department of Fisheries and allied NGOs may play a crucial role.
\end{abstract}

\section{Introduction}

Fish has been occupying an important place in the global food basket as a relatively cheap source of animal protein with higher consumer acceptability. Fish and fisheries have gained considerable importance both as a source of nutrition and as a source of steady and growing income at various levels - individual, state and national. Coming to Bangladesh scenario, fisheries sector's importance in food supply, nutrition, employment generation, poverty reduction, providing animal protein and foreign exchange earning has been reported (Dey et al., 2010; Jahan et al., 2010). Fisheries sector contributes $58 \%$ of animal protein to our daily diet (DoF, 2011). That shows the importance of fish in daily life. But the demand of fish is increasing day by day for the increased population. Annual total fish demand is 2.45 million MT and per capita fish requirement is $18.00 \mathrm{~kg}$ per year. But the current consumption is $16.69 \mathrm{~kg}$ which is below to our expectation (Kausar, 2009). This under consumption has negative influence on the health condition of the people.

In Bangladesh among all other sectors, Agriculture, Forestry and Fisheries occupied $18.70 \%$ GDP share of total Bangladesh economy. Bangladeshi fisheries are contributing more to the country's GDP now i.e. $4.37 \%$ of national GDP and $22.7 \%$ of agricultural GDP (BBS,
2013). The country's export earnings from this is sector are $2.84 \%$ (EPB, 2013). The fisheries sector is considered to be a thrust sector for sustainable development and socio-economic advancement of rural fisherman (Monir et al., 2011). About $11 \%$ of total population of Bangladesh is either directly or indirectly involved in the fisheries sector for their livelihood (DoF, 2012). So fisheries sector is very much influencing both our economic and nutritional level.

Bangladesh is a land of rivers or we can say her land of fishes. In Bangladesh there are 266 freshwater fish species and 15 exotic species (DoF, 2012). Thai koi ( $A$. testudineus) is an exotic species in Bangladesh. The fish is called climbing perch since it can wander across land to find new habitats. In Bangladesh it is introduced from Thailand in 2002 (Kohinoor et al. 2010). Presently, Thai koi is getting more popularity than our native strain because of its high growth rate, and special nutritive qualities (Akter et al., 2010). Thai koi farming is now expanded throughout the country and many hatcheries have been established in our country with a view of producing Thai koi fry, especially in greater Mymensingh, Gazipur and Bogra district (Mahmood 2013). 
Recently fish farmers of Mymensingh region are facing problem for culture juvenile Thai Koi, among which disease outbreak is one of the important issues. Thai Koi looks like our indigenous Koi but its body covers with gray and small black to spots. This fish can be cultivable in pond, tanks and cages successfully.

Once upon time, climbing perch or Native Koi was very much abundant in almost all freshwater systems of Bangladesh (Mahmood, 2013). The availability of this fish is decreasing from natural systems in the recent years. Koi itself contributed $2.83 \%$ of the total pond catch of Bangladesh (DoF, 2012) and now its contribution gradually declined to $1.62 \%$ (DoF, 2014). But still it's a favourable fish for fishers to cultivate in the pond. In 2012-13 Koi farming contributes $2.68 \%$ of the total pond fish culture which is significant for live fish. In Mymensingh, though the culture of Koi fish is significantly high as it contributes $10.22 \%$ of total pond fish culture in 2012-13 alone (DoF, 2014). It is tough culture our indigenous Koi in pond providing supplementary feed rather than possible to culture Thai Koi in pond successfully supplying artificial feed. Thai Koi is considered as an important economic fish species which has high market value and good nutritional profile. It is delicious and can be used as patient food (DoF, 2014).

So we can see that, Thai Koi culture is very important to fulfill nutritional requirement and to generate livelihood opportunities of poor people. Poor people are improving their social and economic condition through Thai Koi culture. Thai Koi culture is profitable but lack of sufficient fund, high price of input, lack of marketing facilities, lack of scientific and technical knowledge, nonavailability of fish seed, water shortage in dry season etc. (Sohel, 2007). But considering the economic and nutritive potentials of Thai koi, a sharp increasing trend has observed on Thai Koi culture in some selected areas of Bangladesh, particularly, it is predominant in several upazilas of Mymensingh district (Kulsum, 2005). But due to meet up the existing demand of fish, more culture of Thai Koi fish is desirable. Considering the above facts, the present study was conducted based on objectives i) to determine extent of attitude of farmers towards Thai Koi farming and ii) to find out the problems of farmers in Thai Koi farming.

\section{Material and Method}

The study was conducted at two villages namely Shaiod and Ahmedpur of Kheruajani Union of Muktagacha Upazila under Mymensingh district. Muktagacha upazila was purposively selected because Thai Koi culture is practiced in an extensive way here and people are highly dependent on Thai koi farming as their major occupation. Besides Thai Koi farmers are more easily available in these two villages than other areas due to their local background (340 farmers possessed Thai koi farming among 1470 Fish farmers in 2012, Upazila Fisheries Office, Muktagacha, Official data, 2013). The selection was made on the basis of suggestions made by
Upazila Fisheries Officer (UFO) and other relevant officials of Muktagacha Upazila. The total number of Thai Koi farm household in these two villages was 340 which constituted the sampling population. In the second step $26 \%$ were randomly selected as sample. Seventy (70) Thai koi Farmers were selected and constituted the sample for this study. Both qualitative and quantitative means of data collection procedures were used in the study. Data were collected through the pre-tested interview schedule by face-to-face interview procedure during April 2015.The interviews, lasting about one hour each, focused on attitude of farmers towards Thai Koi farming and their major problems in Thai koi farming. Cross-check interviews were conducted with SubAssistant Agriculture Officer, researchers and relevant non-government organization (NGO) workers. Data from questionnaire interviews were coded and entered into SPSS software package for analysis.

Examination of attitude of farmers towards Thai Koi farming was the main objective of the study. Fifteen (15) statements were selected during pre-testing of the interview. Ten were positive statements and five were negative statements. A three point rating scale weighing 1 , 2, and 3 for disagree, no opinion, and agree respectively was used positive attitude statements and reverse was used for negative attitude statements. So the possible score for each farmer could range from 15 to 45 for 15 statements. For better understanding, Computed Attitude Score (CAS) was developed to rank order opinion of the attitude statements. So a particular statement could range from 70 to 210 for 70 farmers.

$$
\mathrm{CAS}=\mathrm{Fas} \times 3+\text { Fnos } \times 2+\mathrm{Fds} \times 1
$$

Where,

Fas =Thai Koi farmers agree with the statements

Fnos=Thai Koi farmers having no opinion with the statements

Fds =Thai Koi farmers disagree with the statements

Problem of farmers in Thai koi farming was measured against fourteen selected problem statements. Problem in each item has been presented with frequency distribution of the farmers. Each of the problems were categorized against a scale of no problem, slight problem, moderate problem, high problem, and scored as 0, 1, 2 and 3 respectively. For clear understanding about the problems that farmers are confronting, an index for each item along with rank order was computed by using following formula:

$\mathrm{PCS}=\mathrm{Php} \times 3+\mathrm{Pmp} \times 2+\mathrm{Plp} \times 1+\mathrm{Pnp} \times 0$

Where,

PCS =Problem Confrontation Score (PCS)'

Php =Thai Koi farmers with 'high problems'

Pmp =Thai Koi farmers with 'medium problem'

Plp =Thai Koi farmers with 'low problem'

Pnp =Thai Koi farmers with `no problem’ 


\section{Results and Discussion}

\section{Attitude of Farmers towards Thai Koi Farming}

The observed score of attitude of farmers towards Thai koi farming ranged from 24 - 39 with an average of 31.23 and standard deviation 4.22. Based on attitude score respondents were categorize into three categories such as less favorable attitude (15 or below), moderately favorable attitude (16 to 30 ), highly favorable attitude (31 or above), data presented in Table 1 indicate that most of the Thai Koi farmers were highly favorable category $(60 \%)$ on the basis of their attitude score. It is a good indication that all the Thai Koi farmers in the study area possessed moderate to highly favorable attitude towards Thai Koi farming which may be exploited easily by the extension organizations in promoting Thai Koi farming in the study area.

It is evident from the Table 2 the statement ' $I$ believe that Thai Koi farming in pond can supply protein and nutrition to the family members' ranked first in attitude of Thai Koi farmers. Protein and nutrition are essential for human health. Fish protein are easily digestible than other protein sources like meat and plant protein. So, the farmers can easily accept fish protein.

Second is 'I like Thai Koi farming because it has higher growth rate than that of other local Koi'. Bangladesh is over populated country and need high amount of fish per day. Local Koi are small and growth rates are comparatively slow. So, Thai Koi cultivation is suitable in Bangladesh context.

Table 1 Categories of farmers according to their extent of attitude

\begin{tabular}{cl|lcccc}
\hline Possible range & Observed range & \multicolumn{1}{|c}{ Categories (scores) } & No. & Percent & Mean & Standard deviation \\
\hline \multirow{3}{*}{0 to 45} & \multirow{2}{*}{$24-39$} & Less favorable $(\leq 15)$ & 00 & 0.0 & & \\
& & Moderately favorable $(16-30)$ & 28 & 40.0 & 31.23 & 4.22 \\
& & Highly favorable $(\geq 31)$ & 42 & 60.0 & & \\
\hline & Total & 70 & 100.0 & & \\
\hline
\end{tabular}

Table 2 Ranking of statements for measuring attitude of farmers

\begin{tabular}{|c|c|c|c|c|c|}
\hline \multirow{2}{*}{ Statements } & \multicolumn{3}{|c|}{ Computed Attitude Score (CAS) } & \multirow{2}{*}{ Total } & \multirow{2}{*}{$\begin{array}{l}\text { Rank } \\
\text { order }\end{array}$} \\
\hline & Agree & No opinion & Disagree & & \\
\hline $\begin{array}{l}\text { (+) I believe that Thai Koi farming in pond can supply } \\
\text { protein and nutrition to the family members }\end{array}$ & 210 & 00 & 00 & 210 & 1 \\
\hline $\begin{array}{l}\text { (+) I like Thai Koi farming because it has higher growth } \\
\text { rate than that of other local Koi }\end{array}$ & 204 & 4 & 00 & 208 & 2 \\
\hline $\begin{array}{l}\text { (+) Socio-economic conditions of the villagers are } \\
\text { changing through Thai Koi farming }\end{array}$ & 195 & 00 & 5 & 200 & 3 \\
\hline $\begin{array}{l}\text { (-) I like Thai Koi farming because of lower price of fry } \\
\text { compared to others }\end{array}$ & 7 & 2 & 186 & 195 & 4 \\
\hline $\begin{array}{l}\text { (+) I think Thai Koi farming is more profitable business } \\
\text { than other fish farming like pangas }\end{array}$ & 186 & 00 & 8 & 194 & 5 \\
\hline $\begin{array}{l}\text { (+) I prefer Thai Koi farming because Thai Koi is tasty to } \\
\text { eat }\end{array}$ & 162 & 12 & 10 & 184 & 6 \\
\hline $\begin{array}{l}\text { (+) I like Thai Koi farming because it has high market price } \\
\text { than other fish like pangas }\end{array}$ & 135 & 10 & 20 & 165 & 7 \\
\hline $\begin{array}{l}\text { (-) I believe that drying of the ponds in the winter season } \\
\text { hamper in Thai Koi culture. So, I do not do it. }\end{array}$ & 24 & 00 & 138 & 162 & 8 \\
\hline $\begin{array}{l}\text { (+) I believe that Thai Koi easy to sale compared to other } \\
\text { fish species because of its high price and taste }\end{array}$ & 123 & 14 & 22 & 159 & 9 \\
\hline $\begin{array}{l}\text { (-) The environmental balance is being degraded by Thai } \\
\text { Koi farming }\end{array}$ & 25 & 8 & 123 & 156 & 10 \\
\hline $\begin{array}{l}\text { (-) I dislike Thai Koi farming because cost of farming is } \\
\text { relatively higher than that of other fish } \\
\text { (+) Thai Koi transportation is very difficult than other fish }\end{array}$ & 34 & 00 & 108 & 142 & 11 \\
\hline $\begin{array}{l}\text { like carps because of its strong sword bone present in upper } \\
\text { and lower level of the body }\end{array}$ & 90 & 14 & 33 & 137 & 12 \\
\hline $\begin{array}{l}\text { (+) It is possible to culture Thai Koi and raise vegetable on } \\
\text { pond dike simultaneously. So I practice it. }\end{array}$ & 60 & 4 & 48 & 112 & 13 \\
\hline $\begin{array}{l}\text { (+) It is possible to raise duck and poultry in the same pond } \\
\text { by applying improved technique }\end{array}$ & 48 & 6 & 51 & 105 & 14 \\
\hline $\begin{array}{l}\text { (-) I do not like Thai Koi farming because it is easy to be } \\
\text { affected by disease than other fishes }\end{array}$ & 59 & 4 & 27 & 90 & 15 \\
\hline
\end{tabular}


Table 3 Categories of problems faced by the farmers in Thai Koi farming

\begin{tabular}{cc|lcccr}
\hline \multirow{2}{*}{ Possible range } & \multirow{2}{*}{ Observe range } & \multicolumn{1}{c}{ Categories } & \multicolumn{2}{c}{ Farmers } & \multirow{2}{*}{ Mean } & \multirow{2}{*}{ Standard deviation } \\
\cline { 3 - 5 } $0-42$ & \multirow{3}{*}{$12-27$} & Low problem (up to 14) & 6 & 8.57 & \\
& & Medium problem (15 to 28) & 64 & 91.43 & 20.43 & 3.40 \\
& & High problem (29 to 42) & 00 & 00 & & \\
\hline
\end{tabular}

Table 4 Ranking of problems according to Problem Confrontation Score (PCS)

\begin{tabular}{|c|c|c|c|c|c|c|}
\hline \multirow[b]{2}{*}{ Problems faced by the Thai Koi farmers } & \multicolumn{4}{|c|}{ Farmers $(n=70)$} & \multirow[b]{2}{*}{ PCS } & \multirow[b]{2}{*}{$\begin{array}{l}\text { Rank } \\
\text { order }\end{array}$} \\
\hline & $\begin{array}{c}\text { High } \\
\text { problem }\end{array}$ & $\begin{array}{l}\text { Medium } \\
\text { problem }\end{array}$ & $\begin{array}{c}\text { Low } \\
\text { problem }\end{array}$ & $\begin{array}{c}\text { No } \\
\text { problem }\end{array}$ & & \\
\hline High sensitivity to disease of Thai Koi & 186 & 16 & 0 & 0 & 202 & 1 \\
\hline High price of Thai Koi feed & 186 & 14 & 1 & 0 & 201 & 2 \\
\hline High price of drugs & 186 & 12 & 2 & 0 & 200 & 3 \\
\hline High price of farm labor & 147 & 26 & 13 & 0 & 186 & 4 \\
\hline Unavailability of quality Thai Koi seeds & 84 & 46 & 18 & 0 & 148 & 5 \\
\hline Lack of money for farming & 45 & 58 & 23 & 0 & 126 & 6 \\
\hline Production cost high compared to low profit & 33 & 42 & 37 & 0 & 112 & 7 \\
\hline Lack of water exchange facility & 24 & 36 & 42 & 0 & 102 & 8 \\
\hline Lack of marketing facilities & 15 & 36 & 48 & 0 & 99 & 9 \\
\hline Nitrogen gases present on the pond bottom & 0 & 46 & 43 & 0 & 89 & 10 \\
\hline Lack of knowledge about Koi farming & 0 & 36 & 52 & 0 & 88 & 11 \\
\hline Bloom present on the pond & 0 & 34 & 43 & 0 & 77 & 12 \\
\hline Less security of fish farm & 0 & 10 & 22 & 0 & 32 & 13 \\
\hline Social or political pressure & 0 & 8 & 15 & 0 & 23 & 14 \\
\hline
\end{tabular}

Third one is 'socio-economic conditions of the villagers are changing through Thai Koi farming'. In Bangladesh, $78 \%$ people are directly or indirectly involved with Agricultural activities with fish farming. Most of the farmers of Bangladesh, the socio-economic conditions are low to moderate. But cultivating Thai Koi farmers in Muktagachha upazila are improving their socio-economic condition.

Fourth is 'I like Thai Koi farming because of lower price of fry compared to others'. Maximum farmers are not accepted this statements and showed negative attitude because the price of Thai Koi fry are higher than other local fish fry. As the farmers are not so rich in our country, they have low capital to invest in any business activities.

Fifth is 'I think Thai Koi farming is more profitable business than other fish farming like pangas'. Market prices of Thai are higher than other fish like pangas. The cultivation of Thai Koi is needed shorter time (100 to 120 days). So, Thai Koi farming is profitable business in accordance with farmers' opinion.

The statement 'I do not like Thai Koi farming because it is easy to be affected by disease than other fishes' got least score as maximum farmer did not accept this opinion. Thai koi are very much sensitive to several diseases in Bangladeshi condition.

So we can say that the farmers are very much in favour with the concept of cultivating Thai koi as a good income source for their livelihood. Besides, this type of koi has very good market value in Bangladesh as the price is reasonably lower than other fish varieties. This low price makes it feasible for the low earning people of the country to buy this fish to meet the protein requirement of their family. The positive attitude shown by the farmers may encourage other famers in cultivating Thai koi.

\section{Problem Faced by the Farmers in Thai Koi Farming}

The problem confrontation score of the farmers ranged from 12 to 27 against the possible range of 0 to 42 with an average of 20.43 and standard deviation of 3.40. Based on the problem scores the farmers were classified into three categories. Each of the problems were further categorized against a scale of no problem, slight problem, moderate problem, high problem, and scored as 0, 1, 2 and 3 respectively. The distribution of the farmers according to their problem scores has been shown in Table 3, low problem (up to 14), medium problem (15 to 28), and high problem (29 to 42 ).

The Table 3 revealed that most of the farmers $91.43 \%$ faced medium problems. Only $8.57 \%$ of the farmers faced low problems. Problem score for each statement was calculated by using problem confrontation score and it has been arranged in rank order according to their high problem.

The Table 4 shows that the statement 'High sensitivity to disease of Thai Koi' got the highest problem confrontation score (202) and stood the first rank problem. Thai Koi is easily affected by viral disease. In 
addition appropriate drugs are not available used for recommendation of viral disease.

Second one is 'High price of Thai Koi feed'. There are different feed of different company in the market but price is very high. Thai Koi farmers directly depend on company feed. Because farmers are not efficient to prepare the Thai Koi feed.

Third problem is 'High price of drugs' Different drugs of different company is available in the market but price is very high. Thai Koi farmers are directly dependent on company drugs.

Fourth problem is 'High price of farm labor'. Farm labor are scarce in study area because high price of labor.

Fifth problem is 'Unavailability of quality Thai Koi seeds'. Most of the hatchery owner is not maintained breeding law. So, good quality of seed is not produced in hatchery. Honest hatchery owner are needed to solve this problem.

Despite these problems thai koi farming is a good prospect for the low earning fish farmers as the demand for koi fish is very high in Bangladesh. The production of this koi is also high even after the sensitivity to the disease. But if the problems get proper notice from the concerned authorities' fish farmers will be more motivated in cultivating thai koi. This will open up a good income generating source for the fish farmers.

\section{Conclusion and Recommendation}

As maximum farmers show favorable attitude towards Thai Koi farming, it may be well utilized while any planned program is taken up for development of Thai Koi farming in the locality. The related organizations (Department of Fisheries, NGOs etc.) should go forward with their latest technologies and scientific issues towards attaining sustainable Thai Koi production. As the farmers face medium problems regarding Thai Koi farming, farmers and concerned extension workers should feel that these problems, with their own nature and extent, can affect their Koi farming enormously. These problems should be taken under serious consideration if Thai Koi farming want to progress in the concerned areas. The Thai Koi farmers should follow scientific farming system in achieving a reasonable status of their farming. In order to achieve this, they should receive latest information of fish farming for relevant organization like Department of Fisheries (Department of Fisheries) and other allied organizations. Programs like credit and standard input supply, information support, motivation may help them well.

\section{References}

Akter N. 2010. An economic analysis of pond pangas fish production in a selected are of Trishal upazilla in Mymensingh district. MS Thesis. Department of Agriculture Economics BAU, Mymensingh. 44 p.

BBS. 2013. Statistical Year Book of Bangladesh. Bangladesh Bureau of Statistics, Government of the People's Republic of Bangladesh.

Dey MM, Alam MF, Bose ML. 2010. Demand for aquaculture development: Perspectives from Bangladesh for improving planning. Reviews in aquaculture 2: 16-32.

DoF. 2012. Fishery Statistical Yearbook of Bangladesh. Fisheries Resources Survey System, Department of Fisheries, Dhaka, Bangladesh.

DoF. 2014. Fishery Statistical Yearbook of Bangladesh. Fisheries Resources Survey System, Department of Fisheries, Dhaka, Bangladesh.

EPB. 2013.Annual Report 2013.Dhaka: Export Promotion Bureau, Bangladesh.

Jahan KM, Ahmed M, Belton B. 2010. The impact of aquaculture development on food security: lessons from Bangladesh. Aquaculture research 41: 481-495.

Kausar RM. 2009. Fisheries Knowledge of Pond Owners in Two Villages of Mymensingh District. M.S. Thesis. Department of Agricultural Extension Education, Bangladesh Agricultural University, Mymensingh, Bangladesh.

Kohinoor AHM, Jahan DA, Khan MM, Ahmed SU, Hussain MG 2010. Breeding, seed production and culture technology of koi fish. Extension Manual No.39. Bangladesh Fisheries Institute. Freshwater Station, Mymensingh. pp.16.

Kulsum U. 2005. Culture Status and Disease Investigation of Thai Koi (Anabas testudineus) in Some Selected Upazillas of Mymensingh District. M S. Thesis, Department of Aquaculture, Bangladesh Agricultural University, Mymensingh.

Mahmood SU. 2013. Effect of Different Feed on Larval/Fry II Rearing, Growth and Survival of Climbing Perch, Anabas testudineus (Bloch) in Bangladesh. 36(1): 13-19.

Monir MS, Haque MR, Rahman S. 2011. Study on technical aspects ofPangasius (Pangasianodon Hypophthalmus) farming in Mymensingh region. Int. J. Sustain. Crop Prod. 6(1): 36-42.

Sohel. 2007. Aquaculture Activities and Livelihoods of the Fish Farmers in some Selected Areas of Kahaloo Upazilla, Bogra. M.S. Thesis, Department of Agricultural Extension Education, Bangladesh Agricultural University, Mymensingh. 